Grameen Nabeen Uddugta (NU), new entrepreneur, social business funding education and service in Bangladesh

\author{
Rouf, Kazi Abdur $\bowtie$ \\ York Center for Asian Research, Canada (Kaziabdur56@hotmail.com) \\ Faculty of Environmental Studies, York University, Canada \\ Noble International University, USA
}

Received: 23 October 2016 Available Online: 3 February 2017
Revised: 1 November 2016 DOI: $10.5861 /$ ijrsm.2017.1664

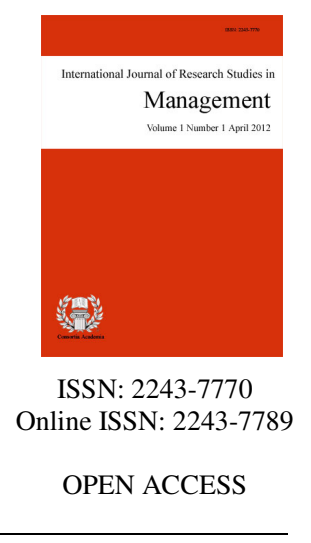

\begin{abstract}
The purpose of this empirical policy research is to explore the policies, procedures, and strategies of the new social business equity funding project of the Grameen sister organizations, and to identify challenges facing second-generation of GB borrowers in running their small social businesses in Bangladesh. The study examines whether second-generation of Grameen Bank (GB) borrowers participate in family and community green enterprises in a more egalitarian way than their parents; examine whether they are involved in recycling/repairing green businesses as an alternative to consumer credit; are these social business borrowers advocates for the Sixteen Decisions of GB (a holistic socioeconomic and environmental messages), for alleviating rural unemployment and social injustice, and for other social issues. The study also look at whether these borrowers encourage their neighbouring unemployed young to be involved in small business in order to address these social issues in Bangladesh. The research findings would help the Yunus Center social business design lab and the social business equity funding implementing agencies Grameen Bank and Grameen sister organizations to improve the social business funding program for better services to second-generation borrowers of Grameen Bank in Bangladesh. The research generates a new knowledge of social financing and green financing, and social and green-enterprise development that could be used by social and community green-financing organizations elsewhere in the world. The findings of the research has shared with Grameen Bank, the later being the Grameen sister organizations' executive.
\end{abstract}

Keywords: Grameen Bank; equity funding; new entrepreneur, social business 


\section{Grameen Nabeen Uddugta (NU), new entrepreneur, social business funding education and service in Bangladesh}

\section{Introduction}

Grameen Bank (GB) has been implementing group-based micro-credit service in Bangladesh since 1976; however, it introduced micro-enterprise loans (Nabeen Udduk (NU) Reen (loan)) for fast-moving as well as second-generation GB borrowers in Bangladesh in 1999 and Grameen Bank Nabben Uddugta social business funding in 2008. During Kazi Rouf's PhD research data collection in Grameen Bank (GB) in 2010, he found that $12 \%$ of GB borrowers had received micro-enterprise loans (loans larger than the GB micro-credit) from GB. This GB micro-enterprise loan size ranges from USD \$400 to USD \$8000. With micro-enterprise loans, fast-moving GB borrowers and their children get involved in micro-enterprise businesses in Bangladesh. This loan is also attracting them to engage in medium-size businesses in Bangladesh. After completing their higher education, many second-generation children of GB borrowers start businesses. Some of them take over their parents' businesses. The NU social business loan/funding project is implementing by the Grameen sister organizations designed by the Yunus Center social business design lab. Now the Grameen NU social business equity funding project has been piloting in Bangladesh since 2013.

Muhammed Yunus resigned from Grameen Bank in 2010, but he carries the idea of the Nabeen Uddugta social business loan with him, and he has been piloting the Nabeen Uddugta social business equity funding (NUSBEF) program through the Yunus Center and the Grameen sister organizations, the latter of which are a little different from GB. Muhammed Yunus is piloting this new social business equity funding investment project through Grameen sister organizations. The Yunus Center and the Grameen sister organizations that over-see the NUSBEF investing program are: Grameen Shakti Samajic Babsah, Grameen Telecom Trust, Grameen Kallyan, and Grameen Trust. These Grameen sister organizations are implementing the NU social business equity funding program in Bangladesh in addition to performing their own jobs. NUSBEF is a partnership equity program between the investing Grameen sister organizations and the Nabeen Uddugta (NU), new entrepreneur, receiving the investment funds. They are using the Yunus Center social business design lab guidelines and formats in implementing the NU social business equity financing program in Bangladesh.

Yunus Centre has been organizing monthly social business workshops/seminars and giving NU social business funds to NUs through the Grameen sister organizations in Bangladesh since 2013. Table-1 contains information on social business equity investment funding to NUs by Grameen sister organizations, apart from Grameen Bank, in Bangladesh.

\section{Table 1}

Grameen sister organizations providing investment funding to NUs

\begin{tabular}{lcccc}
\hline Investing Grameen sister organizations & $\begin{array}{c}\text { Male NUs receiving } \\
\text { NUSBEF }\end{array}$ & $\begin{array}{c}\text { Female NUs receiving } \\
\text { NUSBEF }\end{array}$ & Total & $\%$ \\
\hline Grameen Trust & 521 & 11 & 532 & 26 \\
Grameen Kallyan & 128 & 10 & 138 & 7 \\
Grameen Telecom Trust & 591 & 11 & 602 & 29 \\
Grameen Shakti Samajik Babsha & 756 & 40 & 796 & 38 \\
& Total & 1996 & 72 & 2068 \\
\hline
\end{tabular}

\subsection{Objectives of the Study}

$>$ To know the policies and strategies of GB micro-enterprise loans and incentives provided to second-generation clients of GB by this new loan product; 
$>\quad$ To explore differences among GB micro-credit, micro-enterprise loans and social business loans;

$>$ To examine the business performance status of second-generation borrowers compared to first-generation GB borrowers and to know their motives in encouraging and coaching neighboring poor children for schooling; and

$>$ To discover challenges faced by second-generation borrowers in managing/running their businesses.

\subsection{Specific Objectives}

$>\quad$ To discern motivations of second-generation clients of GB to be involved in micro-enterprises;

$>\quad$ To see if these new entrepreneurs are aware of and work for community issues like the practice of dowries, teenage marriage, school drop-out in child education, emerging tourism and concerns for public security, water pollution, rural sewage, dying rural artisan products, marketing problems, and helping neighboring disaster victims.

\subsection{Research Questions}

$>\quad$ What are the policies, strategies, terms and conditions of GB micro-enterprise and social business equity funding that is applicable for the recipients?

$>\quad$ What incentive is GB providing to second-generation clients?

$>$ How are second-generation clients of GB motivated to pursue social business loans and to get involved in micro-enterprises and in social business?

$>$ How do second-generation businesses perform compared to first-generation GB-borrowing businesses?

$>\quad$ Do GB graduated borrowers and the children of GB borrowers encourage and coach neighbouring poor children for schooling; get involved in public well-being programs/services; develop local community-living economic values?

$>\quad$ What are the challenges he/she faces in running his/her business in Bangladesh?

\subsection{Significance of the Study}

Working-age youth constitute $24 \%$ of the labour force in Bangladesh. However, unemployment rates among Bangladeshi youth (age 15-24) are 9.3\%, for females, 8.6\% for males, and 8.9\% overall (Asia Pacific Youth Employment Network, 2012). Therefore the Grameen young new-entrepreneur social business equity funding program is a very important one and essential for addressing the issue of unemployment in Bangladesh. Many young unemployed are receiving Grameen NU social business equity financing without mortgages from Grameen sister organizations very easily and becoming self-employed. Moreover, NUs are hiring their neighbourhood unemployed youth to work in their businesses. Although the Yunus Center social business equity investment program for unemployed youth entrepreneurs has started recently (2013) as a pilot scheme in Bangladesh, this program has huge scope in Bangladesh. Thousands of unemployed youth has benefited and self-employed through this program. The success of the NU social business investment program would be a model for youth entrepreneurship development in Bangladesh and in other parts of the world.

By the end of 2015, 2068 second-generation Grameen Bank new entrepreneurs received social business equity funding financed by Yunus Cente social business design lab, Dhaka. These new entrepreneurs have pursued social business by receiving social business equity funding averaging USD\$470. In addition, Yunus Center organized social business development seminars and workshops for the new prospective entrepreneur and 
on-going entrepreneurs who have able to expose about Grameen social business equity funding services. Moreover, Yunus Center social business design lab also providing information to NUs about prospective businesses in their areas. The whole process also assesses NU's capability and capacity to run business, find out local business initiatives, build confidence of the NUs, assist entrepreneurs to get new business ideas and develop a business plan. The workshop and seminar also instil awareness of market information and the business safety net, strengthen NUs' management skills, and link them with other similar business initiators to identify business and financial challenges and learn how to minimize business and financial risk and recover from attendant losses. NU also receive post-loan services like post-business counselling, business mentoring and business management training etc. from Yunus Center social business design lab (Yunus Center, 2015).

This research attempted to explore policies and strategies of these two loan programs (the GB micro-enterprise loan and the NU social business equity loan program), identify problems/challenges that are faced by the borrower, and discover their needs. The study explores status of their businesses in Bangladesh as well as discerns whether Grameen micro-entrepreneurs need further support services to improve their social businesses in Bangladesh. Studying these two GB loan programs could assist NU, GB, Grameen sister organizations and the Yunus social business design lab to improve these two programs and their strategies. The study would assist micro-enterprise loan receivers of GB borrowers and the social business equity loan receivers of the second-generation borrowers of GB to get better support service to run and expand their business. This research could provide lessons helpful to other micro-credit institutions (MFI) in Bangladesh and elsewhere. This work also helps the author's future career development too.

Although many studies have been conducted on the impact of Grameen Bank general loans in Bangladesh, there is no study on GB micro-enterprise loans and the Grameen NU social business equity funding program. The study identified problems for the first time. The social business equity funding agencies of Grameen sister organizations can be benefitted from the study. They (implementing agencies) could think about the problems and challenges that are facing by Nus identifies by the study.

\section{Theoretical and Methodological approach of the study}

The researcher developed a questionnaire to collect data using a survey method. A questionnaire containing open-ended and structured questions designed to collect data from randomly selected beneficiaries through face-to- face interviews in Bangladesh. Then beneficiaries (respondents) randomly selected from each selected Grameen sister organizations-Grameen Kallayan, Grameen Shakti Samajik Babsha, Grameen Telecom Trust, Grameen Trust and Yunus Center. Moreover, he used participatory observation, literature review, institutional ethnography (organizational manuals, policies, and text analysis) for this study. The researcher visited Grameen Bank, Grameen sister organizations and Yunus Center to collect relevant data from second-generation of GB micro-entrepreneurs and NU social business equity investment partners. He also attended five workshops of the Yunus Center social business design lab in Bangladesh. The researcher also gather six clients' stories and collected information on Grameen sister organizations' institutional legal structures, operational context, their funding models, operational strategies, procedures, and the challenges they are facing. The researcher maintained a diary when he was collecting primary information and take field notes to record an interviewee's main idea and find secondary data from Grameen web pages and Grameen annual reports.

\subsection{Time table and duration}

The researcher began his research in July 2014 sponsored by Professor Ellie Perkins, Faculty of Environment, York University. The data collection and data processing completed in December 2015. As mentioned earlier the researcher visited Grameen Bank, Grameen sister organizations, Yunus Center in Bangladesh, and process data, analyse data, write report with his own resources and share research findings with executives of Grameen sister organizations and Faculty of Environmental Studies, York University. This research has accepted to present the findings at the Comparative International Educational Society (CIES) Conference 
Grameen Nabeen Uddugta (NU), new entrepreneur, social business funding education and service in Bangladesh held in Vancouver in 2016. The researcher is planned to present this research at the York Center for Asian Research (YCAR), and Social Economic Center, University of Toronto.

\subsection{Screening process to deliver Grameen social business funds to NU in Bangladesh}

The field worker of the Grameen sister organization visits young rural unemployed and finds potential new entrepreneurs (NUs). The field worker discusses the Grameen social business equity investment partnership opportunity with the NU. He/she shares Yunus Center social business design lab guidelines and procedures of the Grameen equity investment partnership program with NU. The field worker discusses this information with the local potential NU through one-on-one counselling as well as workshops and seminars in the village. He/she evaluates the potential NU following the Yunus Center design lab screening process. The potential NU also shares his/her business idea with the field worker of the respective Grameen sister organizations.

The field worker prepares a list of the potential NUs and their rough business ideas, and sends the list to the Dhaka head office of the respective Grameen sister organization. Then the business analyst of the sister organization calls each potential NU to refine his/her business proposal and presents the business plan at the Dhaka Yunus Center design lab workshop. The business analyst and potential NU together develop the business equity partnership investment plan and write all the information in the prescribed form of Yunus center. The screened business plan is submitted to the Yunus Center social business design lab workshop for review and approval.

\subsection{Yunus Center Social business design lab workshop participants}

Grameen social business for Nabeen Uddugta (NU), new entrepreneur, is a new concept and its practice is also new style equity funding which just recently beginning in Bangladesh designed by Yunus Center Social business design lab. Prospective NU is the second generation of GB borrower's unemployed rural youth in Bangladesh. Prospective NU participants for the Yunus social business design lab workshops are: business people, social business practitioners, potential investors/entrepreneurs, the donor community, academics, innovators, social workers, NGO personnel, philanthropists and young entrepreneurs although the workshops are mainly for NUs.

\subsection{Yunus Center social business design lab workshop and procedures for the disbursement of social business}

funds to young new entrepreneurs

The Yunus Center social business design lab is structured to enable brainstorming, and to train and involve its participants in social business. In this process, many new ideas are generated in the workshops, and they assist attending participants in using these ideas in their businesses. People from different backgrounds also join in this program to learn about social business and brainstorm on potential social business ideas. This workshop brainstorms attending participants to develop social business ideas into real-world companies, generates awareness and provides training about social business, creates linkages between investors and entrepreneurs of social business and allows informative exchanges about successful social business projects. As of 21 December 2015, one hundred and sixty-five participants from national and international organizations with diverse background attended the Yunus Center social business executive workshop program, including a large number of international participants (Yunus Center, 2015).

The Yunus Center social business design lab is a meeting-place for people of diverse backgrounds having the same goal: developing social business for the betterment of society. It is a half-day-long program for people who are interested in social business. The prospective NU presents his/her business plan at the Yunus center social business design lab workshop held in Dhaka. 


\subsection{Grameen social business workshops/seminars are using the popular education learning method}

Yunus Center social business design lab workshops and seminars follow popular education learning styles. The workshops and seminars use power points, videos, popular songs/music, jocks/funs and films. Moreover, workshop facilitators facilitate group discussions that enhance two ways interactions of communications among workshop participants. Grameen social business design lab workshops/seminars encourage discussion that follows democratic way of discussion among the attended workshop participants. Facilitators focus Nus' business issues they are facing and struggling with; they respect NUs' voices and choices, values and their business cultures. Grameen social business equity funding scheme beliefs and prefers NUs short-term and longterm goals and visions. Each Grameen social business workshop has an agenda that is prepared according to need of the NUs need. NU shows his/her business products and his/her handicraft products in the workshop. NU social business promotes local living economy, neighbourhood community economy in rural Bangladesh. Moreover, NU discusses his/her family members' lending contribution to the business. He/she also reports in the workshop how his/her family members informally share their time to run his business.

Here family members are informally voluntarily working together to run NU business; they (family members) distribute their time and labour where all family members share their effort to success the business. It is like diverse economic practice where family members of NU contribute their time for the business. It is like household sharing unpaid work. The family members contribute their time for free, but ultimately they receive the benefits (food, housing, clothing etc.) of the business. NU and family members of NU are following popular business educational approach to run the business.

Popular education is education of, for and by the people. According to Paulo Freire (1994) popular education is an educational approach that collectively and critically examines everyday experiences and raises consciousness for organizing and movement building, acting on injustices with a political vision in the interests of the most marginalized. Popular education requires the "learners" to define what they need in order to learn. Lessons are not dictated by a teacher or leader based on what they know or what they think is important (Nadeau, 1996). Popular education is non-hierarchical. The boundaries between learners and teachers are intentionally blurred, with each teaching the other according to their personal skills, knowledge, and lived realities. Popular education also defined as a technique designed to raise the consciousness of its participants and to allow them to become more aware of how personal experiences are connected to larger societal problems. It has the potential to empower people to collectively organize to change issues affecting their lives. The key components to popular education are: Understanding that learning starts with what is important in the lives of the participants; understanding that learning is a process that names and addresses power imbalances in the world, as well as in the collective group; and understanding that the main goal of popular education is to create positive social change. Grameen social business workshops, seminars and training services are following the population education components/elements.

According to Denise Nadeau (1996), popular education refers to the marginalized and exploited people's education for improving the conditions of the poor and oppressed. Gramen social business equity funding is for the disadvantaged poor entrepreneurs in Bangladesh. The Grameen social business entrepreneurs' workshops are not only orient them (NUs) about business management and business plan, but also exposed them to how marginalised NUs could overcome their family struggle, economic struggle and business struggle following the popular education model. Because popular education is an approach that critically examines and learns from the lessons of past struggles and from concrete everyday situations in the present. It is a deeply democratic process; equipping communities to themselves name and create the vision of the alternatives they are struggling for. Grameen social business equity funding workshop and training program respect NUs' knowledge and values. Moreover, the facilitators respect NUs business experiences and expertise. They (workshop facilitators) also pay attention and listen to their challenges that NUs are suffering from. It equips NUs to define their own struggles and to make their voices heard. It involves a process whereby the NUs could collectively pursue their problems although they do business individually. Moreover, they could collectively (family members) solve their business 
problems including identifying the resources, and skills they need. Grameen social business popular learning process develops within the process the consciousness of and commitment to the interests of the marginalised NUs as part of their struggle.

Grameen social business design lab beliefs that NUs have sufficient knowledge/skills on their own that they can work out the solutions to their business problems. So NUs do not need formal business training diploma for receiving Grameen social business NU equity funding. However, researcher does not agree with this Grameen social business design lab notion. Because many NUs reported that they need business financial management skills and trade skills for running their businesses well. However, Grameen social business scheme believes that women and men at the community and grassroots level are the primary agents for social change. Grameen social business brings rural new entrepreneurs ongoing consciousness-raising about the necessity of unemployed NU to initiate social business in rural areas in Bangladesh. Grameen social business intends to promote social purpose community beneficial business that address the issue of youth unemployment, lack of business capital and lack connections/networks among marginalised youth entrepreneurs in Bangladesh. Yunus Center social business lab facilitates business network among the Grameen new entrepreneurs. The motive of the Grameen social business equity funding program is to empower poor unemployed youth to be successful in their business, they become a role model entrepreneurs in their locality that ultimately could impacted economic uplift and social change for the marginalized people in Bangladesh.

\subsection{System of approval of the Grameen social business equity funding to NU}

All business analysts and executives of Grameen sister organizations attend the Yunus Center social business design lab workshop organize for NU. They (Grameen sister organizations' business analysts and executives) review the NU submitted business plan. The business plan and business financing are approved in the workshop after review of the business plan equity funding proposal. The NU receives business funding immediately after approval of the business plan. If any business plan does not satisfy the review team, the NU could resubmit his/her revised business plan at the next workshop.

\section{Table 2}

Year- wise Grameen Bank and Grameen social business design lab funding to NUs

\begin{tabular}{|c|c|c|c|}
\hline Year & NUL distribution agency names & Funds to NUs & $\%$ \\
\hline $2008-2012$ & Grameen Bank (GB)* & 2500 & $49 \%$ \\
\hline 2013 & Yunus Center and Grameen sister organizations & 66 & $1 \%$ \\
\hline 2014 & Yunus Center and Grameen sister organizations & 462 & $9 \%$ \\
\hline 2015 & Yunus Center and Grameen sister organizations & 2068 & $41 \%$ \\
\hline Total & Grameen Bank, Yunus Center and Grameen sister organizations & 5096 & $100 \%$ \\
\hline
\end{tabular}

Note. ${ }^{*}$ Grameen Bank is disbursing NU micro-enterprise loans with its own channel which is different than the Yunus center social business design lab and Grameen sister organizations social business equity funding implementation strategy.

\subsection{Meaning of social business and Nabben Uddugta (NU) social business}

According to Muhammed Yunus, a social business is a non-dividend company dedicated entirely to achieving a social goal. In social business, the investor gets his/her investment money back over time, but never receives dividends beyond that amount. The sole purpose of the business is to solve a predetermined social problem in a sustainable way. A social business operates in a free market like a profit-making business, but the goal of a social business, rather than for profit maximization, is to overcome poverty and attain financial and economic sustainability, and while the investor gets back his or her investment amount, no dividend is given beyond the investment money. The workforce gets a market wage with better working conditions and the investee does business with joy. Many academicians use the term social enterprise which is similar to social business. Social entrepreneurs are influencing the regulatory and investment environments to hold businesses more accountable to their social and environmental performance and to support social enterprises. They reflect 
Rouf, K. A.

enlightened human values (Jack, Mook, \& Armastrong 2009; and Yunus, 2015).

A social enterprise has two goals: (1) to achieve social, cultural, community economic and environmental outcomes; and (2) to earn revenue. Social enterprises are businesses whose primary purpose is the common good. The social entrepreneurs use methods and disciplines and the power of the marketplace to advance their social, environmental and human justice agendas. However, social enterprises are revenue-generating businesses with twist- social and economic objectives following capitalism. Yunus's social business promotes the same objective that is in line with community-beneficial businesses in the U.S.A and the Community Investment Corporations (CIC), which is UK based. The social business accelerates the process of poverty eradication to an unthinkable pace using the same market mechanism which accelerated global prosperity for the rich in the first place (Yunus, 2015).

\subsection{Is Grameen social business equity funding following sweat equity investment system?}

The answer is yes. A NU puts his/her labour and time in the business and his effort that also contributes to his business as business equity. Grameen social business equity considers NU's experience as an asset of his business. NU business equity usually his pre-existing business products, current shop and business assets like machines, fridge, electricity facilities value, car, van, truck etc. that are used in the business.

Sweat equity is a party's contribution to a project in the form of effort and toil, as opposed to financial equity such as paying others to perform the task. Sweat equity has also an application in social business, for example, the owner of social business put his effort and toil to build his business. An auto owner businessman puts his own efforts and toils in his auto-mobile business to increase the value of the vehicle in a sweat equity auto business. Moreover, the term sweat equity explains the fact that value added to someone's own house by unpaid work results in measurable market rate value increase in house price. The more labour applied to the home, and the greater the resultant increase in value; the more sweat equity has been used. Sweat equity usually used in the real estate business or house ownership business where house owner work himself in the construction of the house for the real estate business company. The real estate counts his/her labour wage as an equity value of the house value. Moreover, sweat equity is used to describe the non-financial investment that people contribute to the development of a project such as a start-up business. For example, sweat equity is counted from the founders of the company, as well as advisors and board members. In many situations where some members of a partnership are contributing their money and others are spending time; here partnership composed of cash and non-cash sweat equity. Sweat equity is rewarded the same as cash equity through a distribution of stock or other forms of equity in a start-up business. Sweat equity is important to the successful start-up of a new social business, especially when cash is in short supply. However, it is essential to value sweat equity vigilantly.

Moreover, it needs to be careful and aware that in early stages of a business, it is easy to overvalue it, offering stock-in-exchange for effort. However, over time, such business could become very expensive and erode the equity available to follow-on investors. Sweat equity should be measured in terms of the long term value of the effort, the long term commitment of the entrepreneurs, and the value-added by the social business entrepreneurs to the overall goals of the social business. Sweat equity can also be considered factual and truthful. For example, a homeowner may spend time fixing, repairing, and renovating their home. The value of their efforts is considered sweat equity and adds to the value of the home.

Recently sweat equity has been used to describe a party's contribution to a project in the form of effort- as opposed to financial equity, which is a contribution in the form of capital. In a partnership, some partners may contribute to the firm only capital and others only sweat equity. Sweat equity can be called "stock for services" and sometimes "equity compensation. This type of equity for service programs involving patent lawyers and securities lawyers who specialize in start-up companies as clients. Grameen sister organizations do not add their service cost in a monetary value in the NU social business equity partnership funding rather they charge five percent investment service charge for covering the Grameen portion equity funding cost. The five percent service 
charge is popular to NU. However, this five percent investment service charge by the Grameen equity investing agencies is not covering their service costs. It may be a token charge at the pilot phase of the Grameen social business equity funding. However, the NU is very happy for Grameen five percent service charge fee for maximum five years because it is very cheap for them.

\subsection{Uniqueness of the micro-enterprise and social business equity partnership loan}

The micro-enterprise program/service of GB is a people-centered development program that has multiplier effects among marginalized people (Anan, 2005; Bornstein \& Davis, 2010; Dees, 2003; Gibbons, 1995; Goetz, 2001; Henry, 2006; Harris, 2002; Khandlker, 2005; Mahamud, 2004; and Yunus, 2010; 2008). The second-generation of GB borrower gets involved in micro-enterprise business by using the Grameen social business equity funding (SBEF). The children of GB borrowers have taken up the opportunities offered by the Grameen micro-enterprise loan service and the Grameen social business equity partnership funding program, helping the marginalised GB second generation to become economic and social actors in their communities in Bangladesh (Yunus, 2010). Such a type of social business program could be developed to engage marginalised people through other micro-financing institutions (MFI) in North America and elsewhere.

Researcher Kazi A. Rouf has worked in Grameen Bank and its other sister organizations in Bangladesh for three decades and he found that the different programs of Grameen Bank contributed to reducing poverty and promoting small entrepreneurship, cooperativism and environmentalism in Bangladesh (Bornstein \& Davis, 2010). Yet, even though the Grameen micro-enterprise program and NU social business equity partnership investment program have been working for a few years, there is no research being conducted on these programs. The findings of this study could be learning lesions for Bangladeshi people, American Canadian people and South Asian micro-entrepreneurs and academicians, because many poor entrepreneurs are still seeking micro-enterprise business capital and self-employment support services for their businesses. Because now many social scientists, leaders, philanthropists, academicians and researchers think capitalism has created poverty by focusing exclusively on profit for business. Capitalism creates a selfish civilization, instead of a human-valued civilization. However, business should be dedicated to operating responsibly so that it could make a people's economy in society (Jack et al., 2009; Yunus, 2010).

\section{Findings}

Grameen Bank micro-credit has been widely published in news media, electronic media, social media. Many journals and books published on Grameen Bank activities. However, this paper is talking about Grameen NU social business equity funding services in Bangladesh. Here below the Diagram-1 talks about differences among Grameen group-based micro-credit, Grameen micro-enterprise loans and Grameen social business equity investment funding.

\section{Diagram 1}

Differences among Grameen group-based micro-credit, Grameen micro-enterprise loans and Grameen social business equity investment funding

\begin{tabular}{|l|l|}
\hline \multicolumn{1}{|c|}{$\begin{array}{c}\text { Grameen group-based micro-credit and Grameen micro-enterprise } \\
\text { loan }\end{array}$} & \multicolumn{1}{|c|}{ Yunus Center Grameen social business funding } \\
\hline $\begin{array}{l}\text { Grameen micro-credit is providing micro loan, but Grameen } \\
\text { micro-enterprise loan (GMEL) is a bigger size loan than } \\
\text { micro-credit. GMEL can be received by the fast moving Grameen }\end{array}$ & $\begin{array}{l}\text { Children of GB borrower and rural unemployed youth (outside GB } \\
\text { borrower) can receive Grameen social business funding on equity } \\
\text { basis. Here funds receiver is an individual investment partner of the } \\
\text { Bank borrowers for manufacturing businesses, poultry/dairy } \\
\text { farming, and for medium size business. }\end{array}$ \\
\hline $\begin{array}{l}\text { Borrower of GB borrows loan for six months with 20\% interest rate. } \\
\text { Here there is no equity partnership between borrower and GB. It is a } \\
\text { group-based micro-financing program. }\end{array}$ & $\begin{array}{l}\text { NU (new entrepreneur) receives business equity funding with five } \\
\text { percent fixed interest rate for a period of maximum five years. NU } \\
\text { and Grameen investing agency are joint partners of the businesses } \\
\text { on equity basis. }\end{array}$ \\
\hline $\begin{array}{l}\text { A diminishing method uses for calculating interest rate- interest is } \\
\text { calculated on the outstanding loan amount. }\end{array}$ & $\begin{array}{l}\text { Five percent interest is not on annual basis; rather five percent } \\
\text { interest is on the disbursed loan for five years }\end{array}$ \\
\hline
\end{tabular}




\begin{tabular}{|l|l|}
\hline $\begin{array}{l}\text { Borrower of GB needs to repay his/her loan at weekly the center } \\
\text { meeting every week. }\end{array}$ & $\begin{array}{l}\text { NU repays his/her instalments of the loan every three months. } \\
\text { He/she does not need to attend weekly meeting for repaying his/her } \\
\text { loan }\end{array}$ \\
\hline $\begin{array}{l}\text { Grameen borrower can receive housing loan, student loan for his/her } \\
\text { children's higher education }\end{array}$ & $\begin{array}{l}\text { NU can become the owner of the business property after repaying } \\
\text { his portion of loan and interest. }\end{array}$ \\
\hline Here loan proposal is done informal way & $\begin{array}{l}\text { NU need formally submit and present his/her business equity plan to } \\
\text { Yunus center social business design lab }\end{array}$ \\
\hline No mortgage required & NU must enter into business equity partnership \\
\hline $\begin{array}{l}\text { No need to sign loan documents in the non-judicial stamp by GB } \\
\text { micro-borrower. }\end{array}$ & $\begin{array}{l}\text { NU must sign MOU of the business equity partnership document in } \\
\text { the non-judicial stamp }\end{array}$ \\
\hline $\begin{array}{l}\text { Grameen micro-credit and GB micro enterprise loan have been } \\
\text { available in Bangladesh for more than three decades. It is a regular } \\
\text { national program in Bangladesh. }\end{array}$ & $\begin{array}{l}\text { Grameen NU social business equity funding is a pilot project } \\
\text { initiated by Yunus Center and implemented by Grameen sister } \\
\text { organizations in Bangladesh for only three years to date. }\end{array}$ \\
\hline
\end{tabular}

New entrepreneurs involve in diversified businesses in Bangladesh. They are involved in setup IT centers, community information centers, sports/music/theatre clubs, web-page designing and multimedia studios businesses. Even they engage in businesses like poultry and livestock farming, poultry feed manufacturing and selling, fisheries, equipment leasing, garments manufacturing and marketing, and the manufacturing of leather and ceramic products. Second-generation of GB borrowers run businesses that have promoted much public good and social business in villages in Bangladesh. This progressive Grameen financial program keeps youth in rural social businesses, reducing the tendency of losing them to urban migration.

Below Table 3 shows types of business owned by the new entrepreneurs (NUs), and the second-generation of GB borrowers' who are the receivers of Grameen social business equity funding services in Bangladesh. Table 3 indicates NUs are involve in businesses like establishing kindergarten schools, coaching centers, child care centers, community information centers, and community clubs. Thirty two percentage new entrepreneurs have retailing/grocery businesses, only few (13\%) of them have manufacturing businesses.

Table 3

Types of business owned by NUs of Grameen Bank (GB)

\begin{tabular}{|c|c|c|}
\hline NU businesses & Number & $\%$ \\
\hline Manufacturing & 8 & $13 \%$ \\
\hline Agribusiness/livestock/fisheries & 7 & $12 \%$ \\
\hline Retailing/Grocery & 19 & $32 \%$ \\
\hline Kindergarten/coaching center & 5 & $8 \%$ \\
\hline IT/Electronics & 4 & $7 \%$ \\
\hline Repairing/recycling & 3 & $5 \%$ \\
\hline Processing & 5 & $8 \%$ \\
\hline IT/repairing/recycling & 2 & $3 \%$ \\
\hline Construction & 2 & $3 \%$ \\
\hline Wholesales & 4 & $7 \%$ \\
\hline Others & 1 & $2 \%$ \\
\hline Total & 60 & $100 \%$ \\
\hline
\end{tabular}

Although Bangladesh is an agricultural country, 12\% NUs businesses are in agricultural/livestock/fisheries. The researcher asked NUs about their income turnover status in agricultural production, raising livestock and fish cultivation. They mentioned the incomes from these businesses are not on daily basis. Therefore, it is challenging for them to continue such businesses.

Now-a-days business is very competitive. Table 4 data shows NUs are facing different problems and challenges in their businesses. Here 33\% respondents are suffering from competitions in their businesses; $31 \%$ respondents mention they do not have customer service skills, trade skills, IT skills and financial management skills. The strike, occupied movement and political turmoil in Bangladesh disturb NUs business too. For example, $22 \%$ of NUs reported that they feel business insecurity and physical insecurity because of recent political turmoil in Bangladesh. 
Grameen micro-enterprise loan borrowers and Grameen social business equity loan receivers can run their businesses more competitively and efficiently if they have financial literacy knowledge, business literacy training and other support services.

\section{Table 4}

NUs' facing problems/challenges in their businesses (multiple responses)

\begin{tabular}{lcc}
\hline \multicolumn{1}{c}{ NU' facing problems/challenges in their businesses } & Frequency & $\%$ \\
\hline Competition & 20 & $33 \%$ \\
Buying raw materials from distance place & 8 & $13 \%$ \\
Lack of business and physical security & 13 & $22 \%$ \\
Lack of customer-service skills & 2 & $3 \%$ \\
Lack of trade skills/IT skills & 6 & $10 \%$ \\
Lack of trade skills & 5 & $8 \%$ \\
Lack of financial management skills & 6 & $10 \%$ \\
Business irregular turnover & 8 & $13 \%$ \\
Others (Get big loan from GB, repaying instalment amount is high, fisheries turnover & 31 & $52 \%$ \\
after one year, less capital, carry \& collect hide from different places, more interest, & \\
strike and occupied movement disturb businesses, cash sale, employees problem, & \\
political turmoil, poultry birds death risk and virus problem, heavy rain, cyclone and & \\
storm, repay TK. 13,400 in every months, daily business income information send & \\
SMS message to GB head office every day, not experienced in business, customers & \\
not paying upfront, guardians give less tuition fees etc.) & Total respondents & $100 \%$ \\
\hline
\end{tabular}

\section{Discussions}

\subsection{Direct benefits of the study}

This advanced-level social business research study directly beneficial to Grameen Bank, to Grameen sister organizations, to the Yunus Center social business design lab, and to GB micro-enterprise loan receivers and the second-generation of GB borrower social business equity funding receivers (new entrepreneurs) in Bangladesh. This study gives social entrepreneurs a space to discuss the Grameen micro-enterprise financing experience, Grameen social business equity investment partnership experience connect them to university social business researcher and social enterprise organizations to provide them with the GB micro-enterprise research data.

The unemployed people involve business and engage in constructive public wellbeing different social environmental and civic activities instead involve in subversive activities in Bangladesh. The paper suggests initiate community economic activities for the youth, develop social businesses education, programs/services for them so that they could involve in income generating activities in their communities instead passing idle time plotting/involving in pessimistic thinking and activities. The Grameen new entrepreneur social business equity funding education and services assist youths divert their minds from extremism, pessimistic plots and trauma resulting from politics of war to devote themselves to social businesses like set up kindergarten school, child care center, computer training center, distributing winter clothing to vulnerable poor people, repairing and recycling green social businesses etc. in Bangladesh. Moreover this post-doc GB micro-enterprise financing and Grameen Nabeen Uddagta (NU) social business equity partnership investment research broadens and improves the researcher's knowledge about GB social businesses, the GB financing model, the Yunus center social business financing model and their implications in communities in Bangladesh and elsewhere.

\subsection{Outputs, outcomes, and potential usefulness of the research}

This post-doctoral research touched on the work of the Grameen Bank (GB) micro-enterprise development program, and Grameen social business equity funding (investment partnership with NU) program in Bangladesh. This research can be useful to micro-finance institutions (MFIs) and other social financing agencies in 
Bangladesh, North American, Asian, African and Latin American micro-financing agencies. This report can be learning lesions to Grameen sister organizations those are involving in Grameen social business equity funding services in Bangladesh. Readers can know about their strengths, weaknesses, opportunities of their legal structures, funding models, products and services, operational strategies, policies, and monitoring and accounting systems by reading this report.

\subsection{Benefits of the Grameen NU social business investing program}

Yunus Center reports that there are many benefits of Grameen Nabeen Uddagta Social Business Equity Funding Service in Bangladesh. The benefits are Grameen NU social business equity funding service is an anti-colonial localization process that empowers marginalised poor people in Bangladesh. It is a sustainable business development model in Bangladesh. The researcher observes that second-generation micro entrepreneurs of GB and new entrepreneurs (NUs) of Grameen social business equity funding receivers are involved in businesses like community information centers, sports/music/theatre clubs, web-page designing, multimedia studios, poultry and livestock farming, poultry feed manufacturing and selling, fisheries, equipment leasing, garments manufacturing and marketing, and the manufacturing of leather and ceramic products.

\subsection{Policy Implications}

The GB and Grameen sister organizations have been instrumental in providing income-generating opportunities to poor people (particularly for empowering women through the extension of collateral-free banking) in Bangladesh since 1976. This policy empirical research examined whether the second-generation of Grameen Bank (GB) borrowers could adequately enhance the developmental status of GB women borrowers and emancipate him/her from the dominance of his/her rich business mate in his/her community life. It further explored the GB micro-enterprise loan program and the Grameen Nabeen Uddugta (New Entrepreneurs) social business loan policy, strategy, the barrier GB Nabeen Uddugta borrower faces, and the leadership of this borrower and his/her ability to transfer his/her leadership skills to other public spaces, especially in social enterprise development in his/her community.

Moreover, the research explored whether the Grameen social business loan products and their policies have resulted in increased social business participation by the household of the second-generation of GB borrower, and in the increased tendency of the community toward social development. Using the case of Bangladesh, this policy research brief recommended that GB and Grameen sister organizations should include gender equality in its social business loan product to address the role of women in the family and in the community. The report also asked question is the second-generation borrower of GB able to remove obstacles to economic and social progress and higher education in their life, and are they able to break down patriarchal dominance in society, to alter economic and institutional arrangements, and to promote more choices for women's participation in social business in Bangladesh?

The findings of this policy empirical research assists Kazi Rouf to write a report and a book on the GB micro-enterprise loan, the Grameen Nabeen Uddugta (New Entrepreneur) social loan policy and strategy, and the barriers/challenges the second generation of Grameen NU borrower faces in implementing his/her social business in Bangladesh. It is anticipated that the report would incorporate the support that is needed for the GB micro-enterprise loan borrower and the second generation of Grameen NUs to take part in decisions that pertain to family and community issues in order to promote his/her development in the family social enterprise sphere and for his/her leadership development in the public sphere in his/her community in Bangladesh. The policy empirical research report generates new knowledge in the field of social enterprise management and development. The paper might help the Government of Bangladesh, other Bangladeshi micro-finance institutions, and the governments and non-governmental organizations (NGOs) of many other countries get ideas about the policies and strategies of the Grameen NU social business loan program in Bangladesh. This research can be a lesson for both developed and developing countries, and for NGOs, on the Grameen Bank social business 

product and service, and grow interest in initiating a new-entrepreneur social business equity funding/loan project for the marginalized people in their own country.

\section{Conclusion}

Grameen Bank has been instrumental in providing income-generating opportunities to poor people particularly for empowering woman through the extension of collateral-free banking in Bangladesh since 1976. This policy empirical research provides information on Grameen Bank (GB) second generation borrower, new entrepreneurs' social business equity funding services and their social entrepreneurship developmental status in Bangladesh. The Grameen social business equity funding program is experimenting in Bangladesh by Grameen four sister organizations designed by Yunus Center social business design lab. The study indicates there is a huge market for social business equity financing in Bangladesh. Therefore, it is better to implement the Grameen social business equity funding program fully assigned to an organization. Moreover, the study suggests expanding the NU social business equity funding program to both inside and outside Grameen Bank borrowers' families in Bangladesh. Organize social business open house meetings, seminars, symposiums and workshops in different districts/Upzillas across Bangladesh throughout the year in addition conducting workshop and seminars in Dhaka.

Yunus Center social business design lab could print one page flyer on Nabin Uddugktta social business concept, partnership pattern and design of business proposal. The flyer can contain 'Grameen Social Business' partner agencies' names, investment repayment system and business ownership system etc. These flyers could be distributed to Grameen Bank branches, Grameen Shakti offices, and other field offices of Gramen's sister organizations.

Yunus Center social business design lab could setup a telephone hotline social business service for young entrepreneurs. This hotline service could serve to answer the queries of young new entrepreneurs of Bangladesh. At the initial stage, the piloting of social business implementation services might continue under present system for a while; however, social business program has huge market in Bangladesh. This project has gotten popular. Therefore, a separate implementing agency with an energetic middle age chief executive is essential in Bangladeshfor regularly implementing this program in Bangladesh. Moreover, as GB has a huge network across Bangladesh and there is a huge demand for social business equity loan among fast moving borrowers of GB, Grameen Bank could continue social business funding services to its first moving borrowers too although surprising Grameen bank has squeezed its NU social business funding services after 2012. As mentioned earlier this policy empirical research report generated a new knowledge in the field of social enterprise management in the field of entrepreneurship development in Bangladesh and elsewhere in the world. Detail information with findings about the study is included in the book.

\section{References}

Asia Pacific Youth Employment Network. (2012). The situation of youth employment in Bangladesh. Retrieved from http://apyouthnet.ilo.org/stats/youth-employment-statistics-in-bangladesh

Bornstein, D., \& Davis, S. (2010). Social entrepreneurship: what everyone needs to know? New York, Oxford University Press.

Dees, J. G. (1998). Enterprising nonprofits. Harvard Business Review (January-February), 55-67.

Freire, P. (1994). Pedagigy of hope: Revisiting pedagogy of the opprssed. NY. Continum, Graveline, Fyre Jean. Gibbons, D. (1995). The Grameen reader. Dhaka: Packages Corporation Ltd.

Gibbons, D., \& Meehan, J. (2002). Financing Microfinance for poverty reduction. In S. Daley-Harris \& A. Awimbo (Eds.), More pathways out of poverty (pp. 229-261). Connecticut: Kumarian Press.

Goetz, A. M. (2001). Women development workers: Implementing rural credit programs in Bangladesh. World Development, 24(1), 45-63. https://doi.org/10.1016/0305-750X(95)00124-U

Grameen Bank Annual Report (2012). Grameen Scholarship Program. Grameen Bank. Packages Corporation: 
Rouf, K. A.

Dhaka, Bangladesh.

Henry, S. (2006). How MFIs' and their cliennts can have a positive impact on the environment. Good practices in business development services: How do we enhance entreprenuerial skills in MFIs clients of Alterna Savings Toronto? Paper presented at the Micro Creditt Summit, HaliFax held in November 2006.

Jack, Q., Mook, L., \& Armastrong, A. (2009). Understanding the social economy: A Canadian perspective. Toronto: University of Toronto Press.

Khandlker, S. (2005). Microfinance and poverty: Evidence using panel data from Bangladesh. World Bank Economic Review.

Khusru, A. (2015). Grameen NUs' social businesses. Paper presented at the Social Business Summit, Berlin, Germany, November 5-6, 2015.

Kofi, A. (2005). Message from Kofi Annan. Grameen dialogue \#60. Dhaka: Grameen Trust.

Mahamud, S. (2004). Micro credit and women's empowerment in Bangladesh. In S. Ahamed \& M. Hakim (Eds.), Attacking poverty with micro credit (pp. 153-188). Dhaka University Press Limited and Palli Karma-Sahyak Foundation.

Nadeau, D. (1996). A training guide on popular education and organizing. Toronto: Doris Marshall Institute. Yunus Center. (2015). Yunus center social business design lab. Retrieved from http://muhammadyunus.org Yunus, M. (2008). Creating a world without poverty. Dhaka: Subarna Publications Ltd.

Yunus, M. (2010). Building social business: A new kind of capitalism that serves humanity's most pressing needs. New York: Public Affairs.

Yunus, M. (2015). Social business. Speech at the Social business Summit, Berlin, Germany, 5-6 November, 2015.

Yunus, M. (2015). What is social business? Retrieved from http://muhammadyunus.org 